\title{
Assessment of tannin antifouling coatings by scanning electron microscopy
}

\author{
Natalia Bellotti ${ }^{* 1}$, Beatriz del Amo, Roberto Romagnoli ${ }^{1}$ \\ CIDEPINT - Centro de Investigación y Desarrollo en Tecnología de Pinturas (CIC-CONICET), Calle 52 e/121 y 122, B1900AYB La Plata, Argentina
}

\section{A R T I C L E I N F O}

\section{Article history:}

Received 21 February 2013

Received in revised form 3 January 2014

Accepted 2 May 2014

Available online 28 May 2014

\section{Keywords:}

Biofouling

Scanning electron microscope

Coatings

Biocide

Tannin

\begin{abstract}
A B S T R A C T
It is well known that during the first minutes of the immersion of any substrate in marine environments microbial colonization takes place. This event will condition the attachment of other more complex organisms and the substrate biodeterioration with concomitant loss of its functionality. The aim of this work was to assess antifouling coatings performance at early stages of immersion, in natural and artificial sea water, observing the surface condition, by scanning electron microscope (SEM), in order to predict possible results in long time immersion tests. The use of short time tests to predict future behavior is useful to adjust formulations, reduce testing time and economics cost.

In this research antifouling (AF) coatings formulated with two "quebracho" tannin derivatives were chosen to be evaluated by short and long time tests. One of this coatings possessed in a longer service life, until 10 months of exposure, and at the same time, this resulted correlated with surface analysis at early stages of immersion by SEM.
\end{abstract}

(C) 2014 Elsevier B.V. All rights reserved.

\section{Introduction}

Coatings deterioration is concerned with physicochemical gradual changes, in coatings properties during their service life which can cause the coating to lose its functionality. The performance of conventional AF coatings (soluble matrix type) rests upon the dissolution of the matrix and the biocide leaching which, in turn, contribute to coating deterioration; as consequence these factors must be balanced to reach an adequate antifouling efficiency. It has been postulated that the activity of AF coating depend of the erosion process, the surface hardness and the leaching of biocides [1,2]. For a more complete picture an AF coating performance, hydration, water diffusion within the film, the hydrolytic degradation of the matrix and the diffusion of biocides should also be taken into account. In addition to these processes, the colonization of the substrate by different organisms present in the marine environment starts immediately after immersion and contribute to coating deterioration.

The biofouling can be defined as the undesirable accumulation of micro and macroorganisms on hard substrates [3] and must be distinguished from other accumulations as corrosion products, salts,

\footnotetext{
* Corresponding author. Tel.: +54 221483 1141; fax: +54 2214271537.

E-mail addresses: pinturashigienicas@cidepint.gov.ar, nataliabe9@hotmail.com (N. Bellotti).

1 UNLP, Professor
}

particulate matter, debris, etc. The colonization of the immersed surface starts with the formation of a conditioning film constituted by polysaccharides, glycoproteins, lipids, nucleic acids, amino acids, monosaccharides, ions, etc., which allows the attachment of bacteria to the so conditioned surface [4-6]. Most forms of microbial adhesion implies the permanent attachment of the organism to the surface by extracellular polymeric substances (EPS) [4]. The main components of EPS are polysaccharides; but it may also contain proteins, glycoproteins and extracellular DNA [7]. Bacterial adhesion and growth, both contribute to biofilm formation; from early times, it was observed that the settlement of invertebrate larvae was influenced by the marine bacterial biofilm [4,8]. After bacterial growth, colonization by unicellular eukaryotic organisms is followed by multicellular eukaryotes [9-11]. There is evidence about the existence of diffusible signal molecules produced by bacterial biofilm which affect the settlement of Enteromorpha zoospore [12].

The biofilm can alter the leaching rate of biocide due to the modification of the coated surface or as a result of the barrier established between the painted surface and the sea water environment [13]. The matrix dissolution is influenced not only by the formation of the biofilm but also by the mechanical erosion caused by sea water and by the diffusion of soluble components of the coatings [13]. Recent studies have also reported changes in the paints leaching rate by the growth of the biofilm which caused the $\mathrm{pH}$ of the film to decrease by the microorganisms metabolism and/or the retention of the biocide by macromolecules of EPS [13,14]. The biofilm development has been studied on some substrates by SEM [15-17]. This 
technique allowed to know different aspects concerning the biofilm such as its formation during the first weeks of immersion, the role of EPS for firm adhesion to substrate and the changes in biofilm' composition on different substrates.

The colonization of different metallic structures submerged in natural waters produces large economic losses particularly by corrosion and in the case of ships an important increase, up to $40 \%$, in frictional drag [18]. Therefore, antifouling paints are a key factor to prevent the settlement of micro and macroorganisms which promote substrates deterioration. New AF paint formulation are required to be efficient and, at the same time, not harmful to the environment. In this sense, recently published research points out the advantage of employing naturals active compounds as biocides in the formulation of soluble matrix AF coatings [19]. The aim of this research was to assess the deterioration of AF coatings formulated with a "quebracho" tannin derivative, a natural biocide, when submerged in artificial and natural sea water (ASW and NSW, respectively) employing SEM and environmental scanning microscopy (ESEM). SEM was employed to assess coatings deterioration in ASW in controled conditions without biofouling. In change, ESEM was chosen to assess microfouling settlement after short immersion time ( $48 \mathrm{~h}$ ) in the NSW environment. ESEM offers an additional advantage in the sense that specimens can preserve their original morphology and moisture condition due to the use of low vacuum and without depositing a conductive coating on it. Results obtained in both environments were correlated in view to develop a quick procedure to assess coatings AF efficiency. It must be taken into account that traditional NSW immersion tests are prolonged in time (generally more than 6 months) and more expensive than those carried out in laboratory [20]. The procedure described in this paper was intended to be useful to make a quick selection of candidate coatings to more extended test in natural environment.

\section{Materials and methods}

\subsection{Preparation of "quebracho" tannin derivatives and their characterization}

Two "quebracho" tannin derivatives were obtained following the procedure reported previously [19]. The derivatives were obtained at two different temperatures, 20 and $60^{\circ} \mathrm{C}$, and named as TZn20 and TZn60, respectively. The composition of the TZn20 and TZn60 were obtained by a gravimetric procedure. Zinc was determined as zinc oxide by heating the solids at $900^{\circ} \mathrm{C}$. The amount of water was determined by indirect gravimetric, heating the solid at $105 \pm 5^{\circ} \mathrm{C}$. The amount of tannin was calculated as the difference between the mass of the dried "tannate" and the zinc oxide content. The density of the pigment, needed for coating formulation, was obtained according to a standardized procedure [21]. The FTIR spectra of both derivatives were obtained using the potassium bromide disc technique and a Perkin-Elmer Spectrum One FTIR Spectrometer.

The solubility of the both derivatives in ASW was determined as described in a previously published paper $[19,22]$. The ASW was prepared according to ASTM D1141-98 [23]. The concentration of tannin in the saturated solution expressed as total polyphenols (TP) was obtained spectrophotometrically at $750 \mathrm{~nm}$ using FDr and was expressed as mg/l of TP [24-26]. In every case tests were run in duplicate.

\subsection{Bioassay}

The concentration of "quebracho" tannin derivatives which kills $50 \%$ of the Artemia nauplii population within $24 \mathrm{~h}\left(\mathrm{LC}_{50}\right)$ was determined using a short term toxicity test [27]. Toxicity tests with
Table 1

Composition of coatings.

\begin{tabular}{lllll}
\hline Components & $\begin{array}{l}\text { "Quebracho" } \\
\text { derivative }\end{array}$ & Chalk & WW rosin & Oleic acid \\
\hline \% of solids by volume & 27.0 & 18.1 & 45.1 & 9.8 \\
\hline
\end{tabular}

Artemia nauplii are quick to carry out, low cost and have good predictive potential. They constitute an interesting alternative to other test with crustacean species as barnacles (Balanus amphitrite) $[28,29]$.

Saturated solutions of TZn20 and TZn60 were diluted adequately with ASW to prepare different solutions containing 10,50,100,120, $300 \mathrm{ppm}$ and $5,10,15,30,60 \mathrm{ppm}$ of TP, respectively. Ten nauplii were placed in a vessel with $10 \mathrm{ml}$ of the respective diluted TZn solution to the control ASW. Copper sulphate was used as positive control being the concentrations of the testing solutions 1.0, $10.0,50.0,100$ and $200 \mathrm{ppm}$, respectively. Three replicates were set up for each concentration, including the controls. After an incubation period of $24 \mathrm{~h}$, dead larvae were counted and $\mathrm{LC}_{50}$ values were calculated by Probit analysis [30].

\subsection{Formulation and preparation of coatings}

The coatings $1-3$, Table 1 , were elaborated with WW rosin as film forming material and oleic acid as plasticizer according to the previously cited investigation [19]. Coating 2 was elaborated with the same formulation but with $2 \%$ by weight of zinc oxide, respect to the total coating formulation. It is known that the alkaline oxide decreases the acidity imparted by rosin and reduces its dissolution rate. The control coating was elaborated with the same formula but the "quebracho" tannin derivative was replaced, by volume, by the extender pigment. As a general rule, three coated panels per coating were assessed in the different proposed assays.

\subsection{Determination of leached polyphenols in ASW}

Coatings were applied on $8 \mathrm{~cm} \times 8 \mathrm{~cm}$ sandblasted acrylic panels. Three or four coats were applied and allowed to dry $24 \mathrm{~h}$ between each application. The total dry film thickness was $120 \pm 5 \mu \mathrm{m}$. Not more than $48 \mathrm{~h}$ elapsed for the painted panels to be submerged in plastic container containing $150 \mathrm{ml}$ of ASW. The leached "tannate" was determined on a $2 \mathrm{ml}$ aliquot using the FDr. The original level of the liquid in the containers was restored periodically with distilled water and the $\mathrm{pH}$ was adjusted to 8.2.

\subsection{Superficial analysis of coatings by SEM and ESEM}

The surface morphology of experimental coatings was analyzed by SEM after exposing them in ASW and NSW. Acrylic panels $(2 \mathrm{~cm} \times 2 \mathrm{~cm}$ ) were coated with experimental AF paints up to $120 \mu \mathrm{m}$ thickness. A set of panels was left in laboratory atmosphere $\left(20 \pm 2{ }^{\circ} \mathrm{C}, \mathrm{RH} 70 \%\right)$, another group was immersed in normally aerated ASW and the remaining set was submerged in Mar del Plata harbor $\left(38^{\circ} 08^{\prime} 17^{\prime \prime}-57^{\circ} 31^{\prime} 18^{\prime \prime} \mathrm{W}\right)$ to monitor the biofilm growth.

Panels immersed in ASW were taken off the containers after 2 and 30 days, respectively, rinsed with distilled water and dried in an oven at $45 \pm 5^{\circ} \mathrm{C}$ for $48 \mathrm{~h}$ to be finally observed by SEM employing a Phillips 505 SEM coupled with EDX microprobe PRIME OX 10 to obtain the surface concentration of the elements. The instrument calibration was performed with a $\mathrm{Zn} \mathrm{(30 \% )-Cu} \mathrm{(70 \% )} \mathrm{alloy}$ with respect to the gain and position of the peaks in the spectrum. Panels without exposition in sea water were also observed by SEM and served as control. The assessment of the surface condition in this short term test was intended to serve as a tool for predict the behavior in NSW exposure test. 


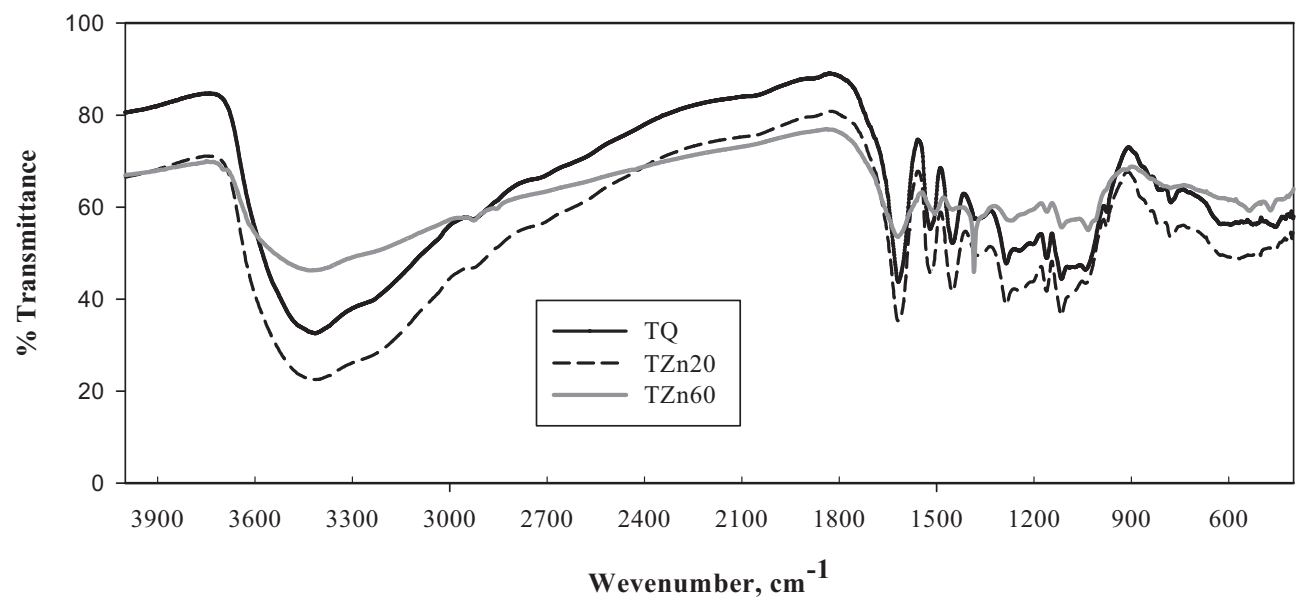

Fig. 1. IR spectrum of "quebracho" tannin (QT) and its derivatives (TZn20/TZn60).

In order to preserve biological structures, panels exposed to the environment NSW were extracted after 2 days of exposure and stored in a $2.5 \%$ glutaraldehyde solution in sea water until their observation by ESEM $[31,32]$. The samples exposed to NSW were examined by ESEM employing a Philips, model FEI Quanta 200 to assess microfouling settlement.

\subsection{Evaluation of coatings AF efficiency in NSW}

Sandblasted acrylic panels $(12 \mathrm{~cm} \times 8 \mathrm{~cm})$ were painted as described previously to a total dry film thickness of $180 \pm 5 \mu \mathrm{m}$. No more than $48 \mathrm{~h}$ elapsed before the painted panels were immersed 50-60 cm deep at Mar del Plata harbor [33].

Fouling resistance (FR) was evaluated according to ASTM D3623-78a and ASTM D6990-05 [34,35], employing a scale from 0 to 100 . The FR of a coating free of adherent biofouling was recorded as 100 . The percentage of the area covered by macrofouling was deducted from 100. A coating free of macrofouling settlement, but with adherent slime (microorganisms such as bacteria, fungi, diatoms and protozoa), must be recorded with a $F R=99$. Therefore, fouling rating directly reflects non-fouled area. Distance smaller than $1 \mathrm{~cm}$ from the edge of the panels were not considered. Uncoated panels were used as control and immersed in the same conditions as the painted ones. Organisms such as barnacles, serpulids, ascidians, bryozoans, algae and polychaetes are frequent in Mar del Plata harbor and were found attached onto the panels $[33,36]$. This assay was conducted in triplicate. The standard deviation of the results was calculated and found to be equal to 4.67. Based on this standard deviation, the acceptability of results was judged at the $95 \%$ confidence level [34].

\section{Results and discussion}

\section{1. "Quebracho" derivatives characterization}

The chemical composition and the density of both derivatives, TZn20 and TZn60, are shown in Table 2. The concentration of TP in the saturated solution of TZn20 and TZn60 in ASW, obtained spectrophotometrically with the FDr, was found to be equal to 3332 and 373 ppm, respectively.

The FTIR spectrum of QT, TZn20 and TZn60 exhibited an intense broad band around $3000-3700 \mathrm{~cm}^{-1}$ which corresponds to the stretching of the $\mathrm{OH}$ group (Fig. 1). Band broadening observed in every case was attributed to a larger number of hydrogen bonds
[37]. The decreases of such band, in the case of TZn60, would be indicating a lower amount of $\mathrm{OH}$ groups due to the interaction of these groups with zinc cations. The observed bands at 1620 and at $1290 \mathrm{~cm}^{-1}$ correspond to the stretching of the $\mathrm{C}-\mathrm{O}$ bond linked to the aromatic units. The two bands at 1520 and $1450 \mathrm{~cm}^{-1}$ were attributed to the stretching of $\mathrm{C}=\mathrm{C}$ bond of the aromatic ring. The band at $1230 \mathrm{~cm}^{-1}$ corresponds to the $\mathrm{C}-\mathrm{O}$ bond of phenols and that at $\sim 1120 \mathrm{~cm}^{-1}$ the vibration of the $\mathrm{C}-\mathrm{O}$ bond $[38,39]$. Therefore, an increase in the synthesis temperature of tannin derivatives resulted in an increased reactivity of polyphenols with zinc and a lower solubility.

\subsection{Bioassays}

After an incubation period of $24 \mathrm{~h}, \mathrm{LC}_{50}$ were found to be $117 \pm 24$ and $17 \pm 3 \mathrm{ppm}$ for TZn20 and TZn60, respectively. The positive control (copper sulphate) was $7 \pm 2.0 \mathrm{mg} / \mathrm{l}$. These results showed that both derivatives were active against Artemia persimili larvae being the derivative obtained at $60^{\circ} \mathrm{C}$ about 7 times more active than that obtained at $20^{\circ} \mathrm{C}$.

\subsection{Determination of leached polyphenols as a function of time}

Results of the leaching experiments are shown in Figs. 2-5. The cumulative amount of TP leached from coating 1 formulated with TZn20, was higher than that from coatings 3; these result correlated with the major solubility of TZn20. The addition of $2 \%$ of $\mathrm{ZnO}$ to coating 2 decreases the amount of leached TP. The formation of less soluble resinates between rosin and zinc ions reduced the dissolution rate of the binder (Fig. 2). The leaching rate (Fig. 3), at every time interval, from coating 1 was sensible higher than for coatings 2 and 3, particularly during the first fortnight of immersion. At the end of the test period the leaching rate of the coating 1 was $\sim 6 \mu \mathrm{g} \mathrm{cm}^{-2} \mathrm{day}^{-1}$ while coating 2 and 3 approached to

Table 2

Composition of "quebracho" derivatives.

\begin{tabular}{llc}
\hline Components & \multicolumn{2}{l}{ Composition $(\% \mathrm{p} / \mathrm{p})$} \\
\cline { 2 - 3 } & QZn20 & QZn60 \\
\hline Tannin & 86.70 & 77.47 \\
Humidity & 12.77 & 13.31 \\
Zinc & 0.53 & 9.22 \\
\hline
\end{tabular}




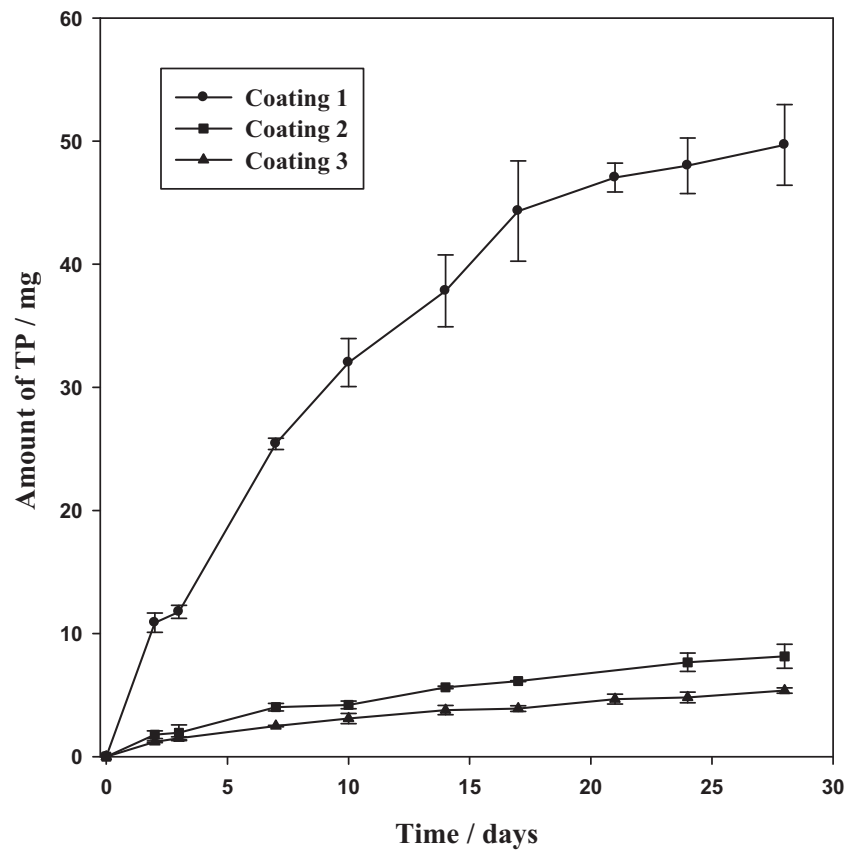

Fig. 2. Amount of tannin leached from the coating films.

$\sim 2 \mu \mathrm{g} \mathrm{cm}^{-2} \mathrm{day}^{-1}$ Fig. 3 . The reproducibility of the test was acceptable and the variation coefficient was found to be $\sim 6 \%$.

The concentration of $\mathrm{Zn}^{2+}$ leached from coatings 1 and 2 was less than $0.1 \mathrm{ppm}$, the detection limit of the atomic absorption (AA) technique. On the other hand, $\mathrm{Zn}^{2+}$ leached from coating 3 was detectable by AA. $\mathrm{Zn}^{2+}$ lixiviation increased sharply during the first two days of immersion and then showed a slight increase as time elapsed (Fig. 4). Plotting the leaching rate of $\mathrm{Zn}^{2+}$ in a given interval of time, it could be seen that this approached a fairly constant value, $\sim 1 \mu \mathrm{g} \mathrm{cm}^{-2} \mathrm{day}^{-1}$, after the first five days of testing (Fig. 5).

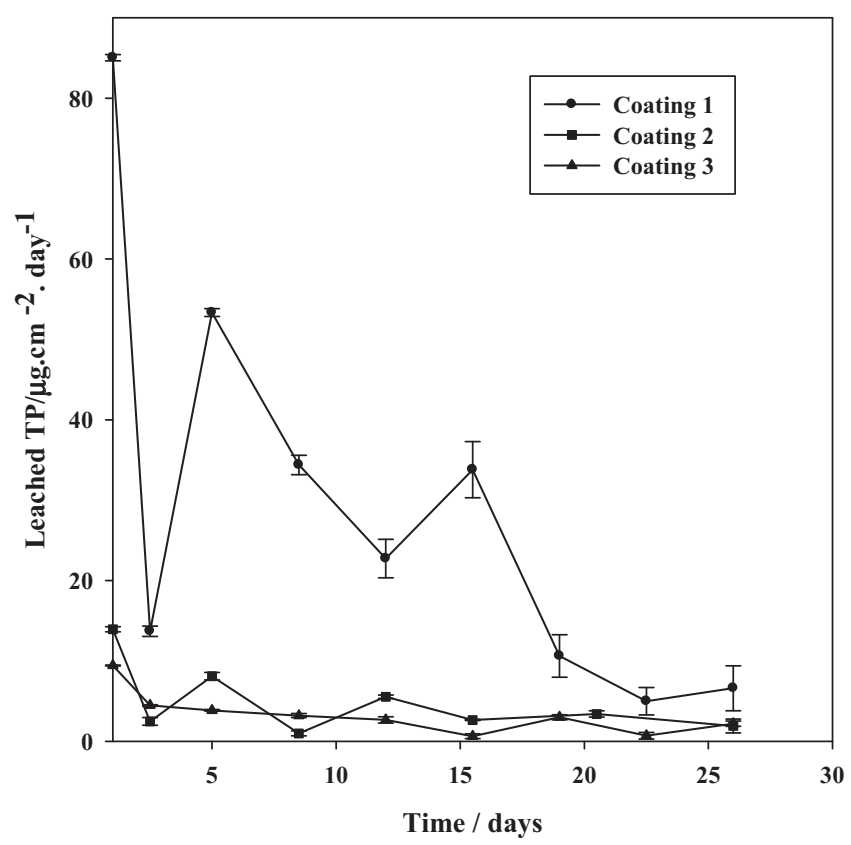

Fig. 3. Rate of tannin leaching from the coating films.

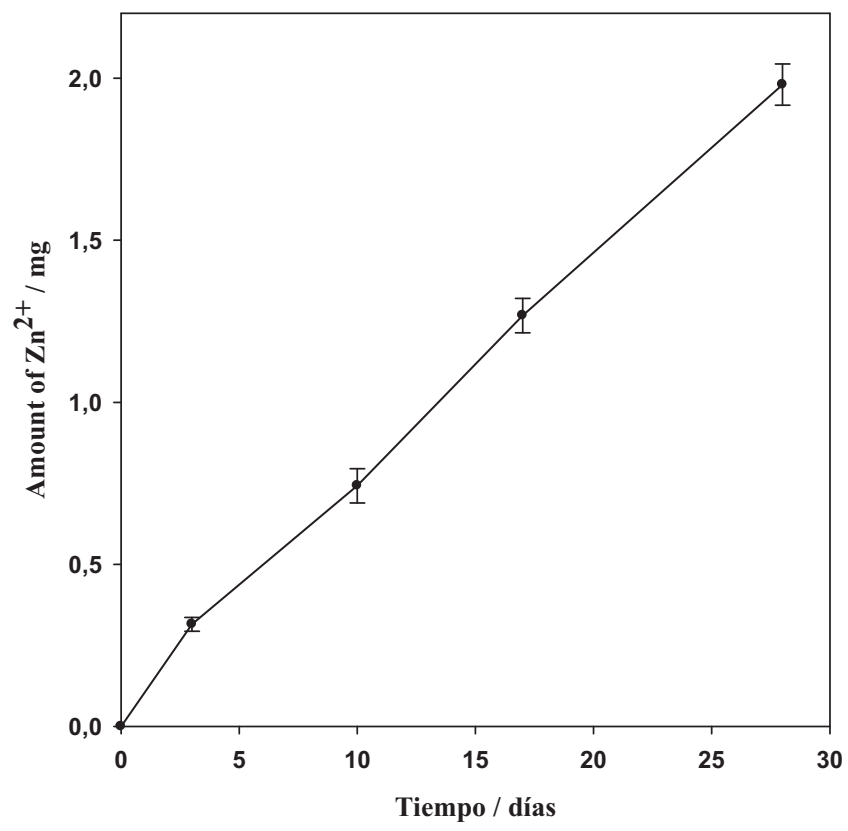

Fig. 4. Amount of zinc ions leached from the coating 3.

\subsection{Superficial analysis of coatings by SEM and ESEM}

The appearance of the coatings before ( 0 day) and after ( 2 and 30 days) immersion in ASW may be seen in Fig. 6a and b which contained the corresponding EDX spectrum.

Unexposed film (Fig. 6a, 0 day) presented a similar morphology with white particles formed by calcium carbonate and magnesium carbonate from the extender pigment. The surface concentration of zinc previous to immersion was undetectable in the case of coating 1, but was found to be 1.23 and $1.79 \%$ for coatings 2 and 3 , respectively (Fig. 6b, 0 day).

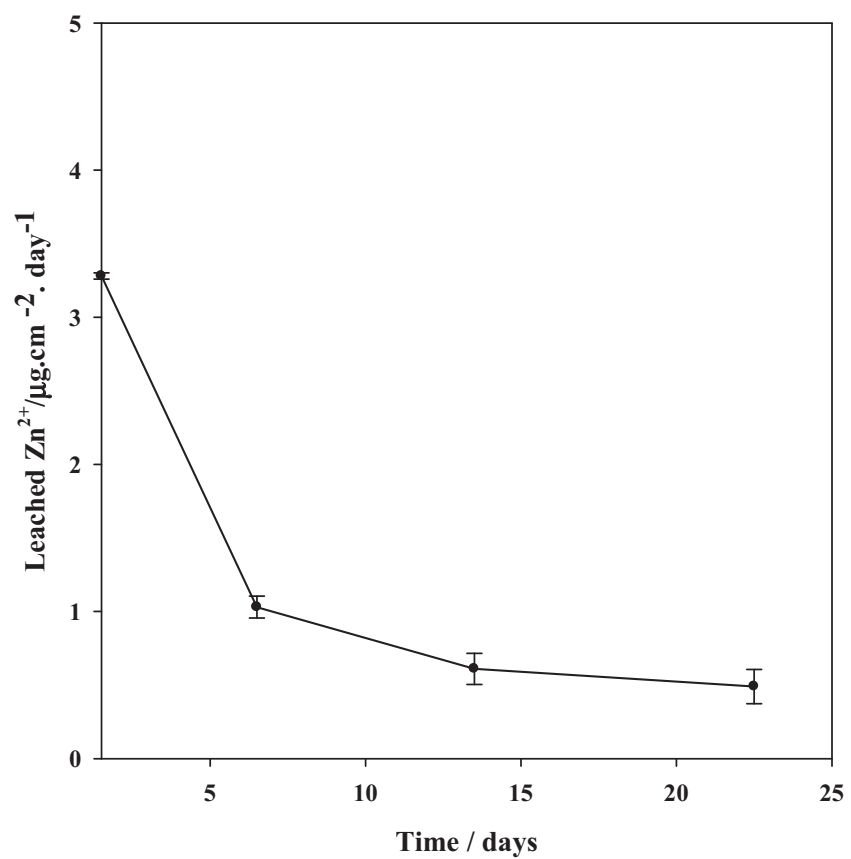

Fig. 5. Rate of zinc ions leaching from the coating 3. 

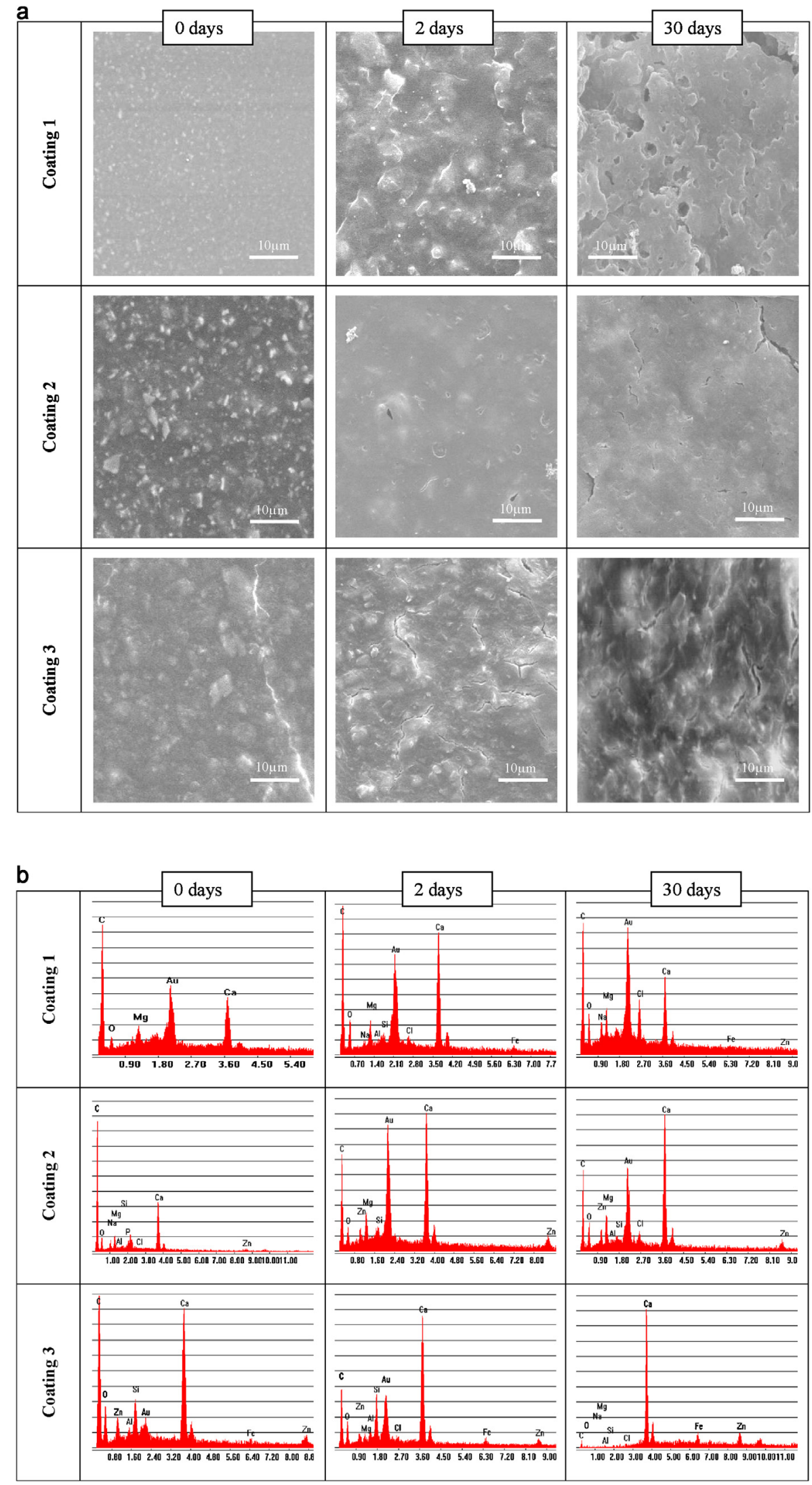

Fig. 6. (a) SEM micrograph: panels with 0,2 , and 30 days of the exposition in ASW (observed cracks respond to high vacuum conditions). (b) Microanalysis of the coatings by EDX: panels with 0,2 , and 30 days of the exposition in ASW. 


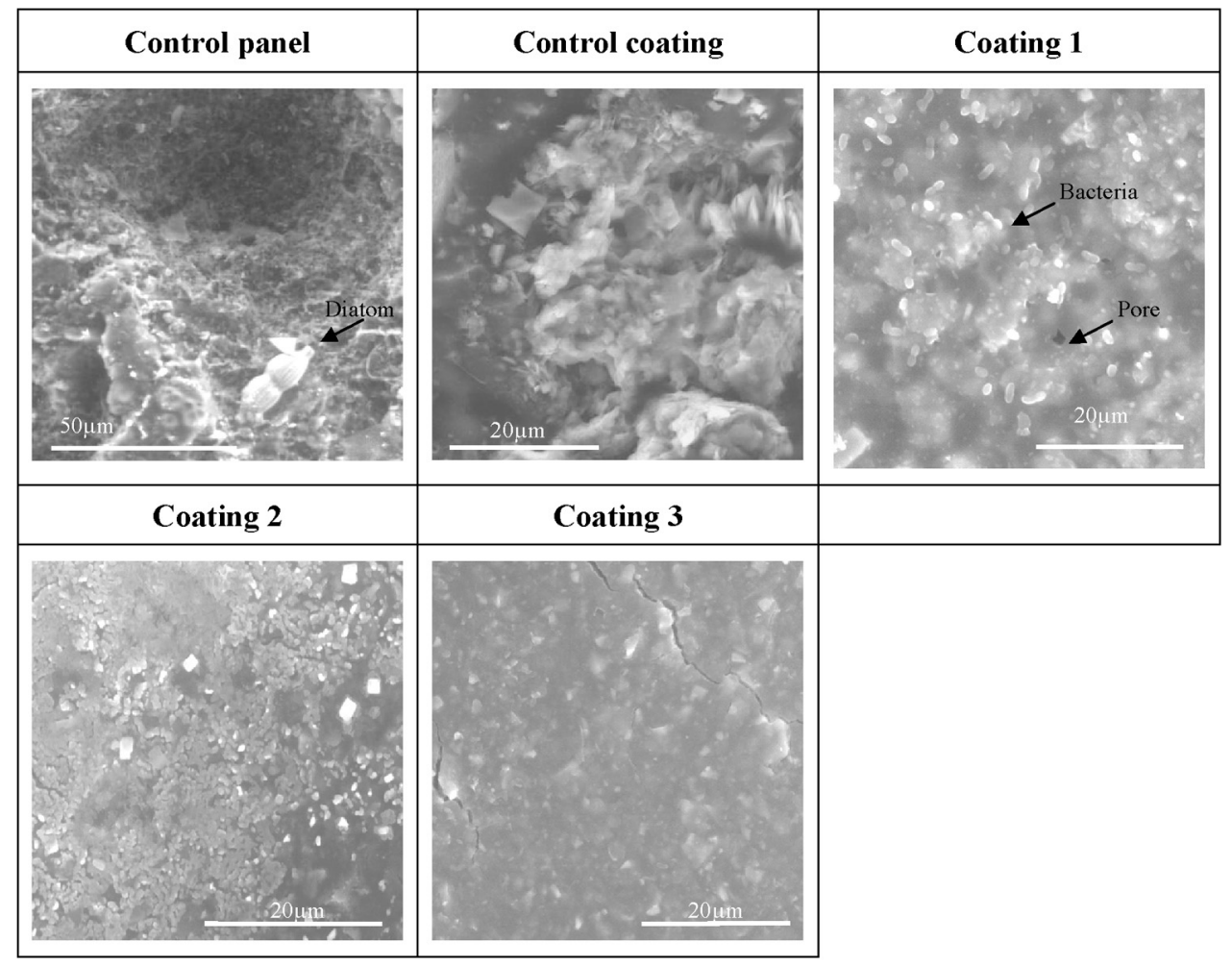

Fig. 7. ESEM micrograph: controls and coatings 1-3 with 2 days of the exposition in NSW.

After 30 days of exposure in ASW, coating 1 showed large pores and an incipient surface wear. This fact correlated with the high leaching rate recorded for this coating (Fig. 3). The increase in the signal corresponding to $\mathrm{Na}$ and $\mathrm{Cl}$ was attributed to an intense circulation of ASW through the pores of the paint film which would certainly affect its efficiency, facilitating the dissolution of the binder and the release of biocide to the environment. The irregular surface observed for coating 1 would indicate a greater vulnerability to bacterial settlement and growth.

In change, coatings 2 and 3 showed a more homogeneous and compact film without pores. The surface morphology did not change substantially between 2-30 days of immersion. It is interesting to point out that the addition of $2 \%$ of zinc oxide led to a significant improvement in the surface properties of the coating (Fig. 6a, coating 2, 30 days).

Surface elemental analysis of coatings $1-2$ revealed an increase in the Mg and Ca contents (Fig. 6b). This seemed to indicate that the coating surface accumulated products coming from the reaction of tannin and rosin with seawater cations. It was also reasonable that the $C$ content decreases due to solubilization of the binder and the leaching of tannin from the coating.

ESEM micrographs of the controls (panels without coating and with control coatings) and the experimental coatings 1-3 after 2 days of immersion in NSW are shown in Fig. 7. A greater degree of colonization was observed on the control panels and control coating (without any type of biocide) which exhibited the formation of a layer of abundant biofilm with some diatoms.

The thin biofilm grown on coatings presented less diversity and was mainly constituted by rod-shaped bacteria. This would result in a delay in the second stage of the substrate colonization by other organisms like diatoms or protozoa. Actively grown bacteria around pores of coating 1 can be seen in Fig. 7. The bacterial colonization on coating 1 contributed to the high deterioration observed in immersion tests in the natural environment as it will be shown below. In the case of coatings 2 and 3 no was observed biofilm formation after 2 days of exposure. These observations correlated with results in NSW immersion and resulted in an extended useful life for coatings 2 and 3.

\subsection{Essays in NSW}

Once immersed in NSW, coated panels were observed periodically to determine the AF efficiency of tested coatings according to the selected scale, ASTM D6990-05 [35] (Fig. 8a and b). After the fourth month of immersion control panels exhibited a great amount of attached organisms (mostly ascidians, bryozoans, serpulids and algae) resulting the $F R=0$. In the case of the control coating, without biocide, FR was found to be 39 , higher than the control panels, but much lower than coatings $1-3$ (Fig. 8). The amount of settled organisms increase over time, being the FR=0 at the ninth month of immersion for the control panels (Fig. 8a). Coatings 1-3 exhibited a high AF efficiency ( $F R=99)$ but, for the sixth month, coating 1 showed a high wear and panels were taken off the exposition site (Fig. 8b). Coating 2 presented a good behavior $(F R=80)$ after sixth months of testing but showed incipient wear which became worse as time elapsed, causing the test to be finished at the seventh month of exposure. Coating 3 was the most efficient one $(F R=90)$ after ninth month, keeping a complete film integrity. However, 1 month later increased attachment of macrofouling, such as serpulids and acidians, was observed although film integrity maintained over the entire panel, both the antifouling protection and film integrity was favored with the pigment obtained at $60^{\circ} \mathrm{C}$ (Fig. 8b). 
(a)

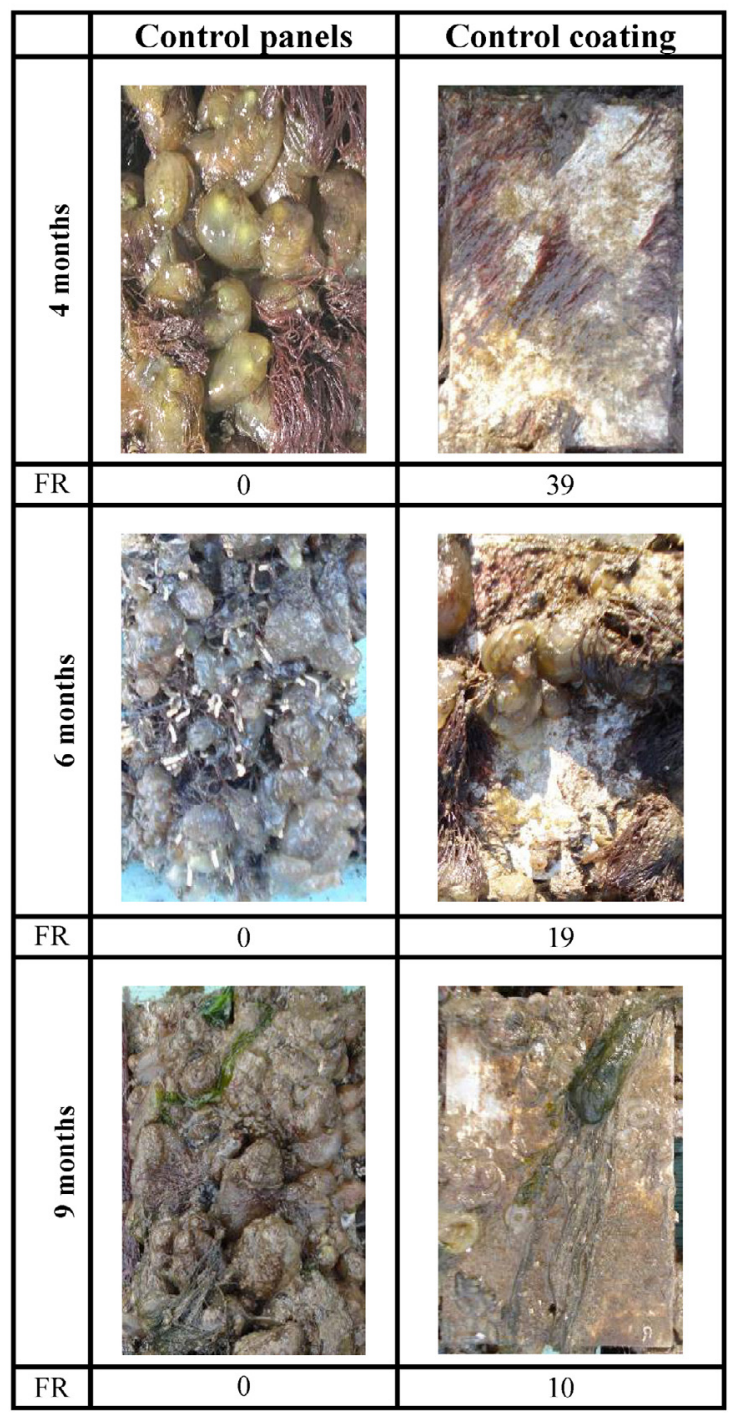

(b)

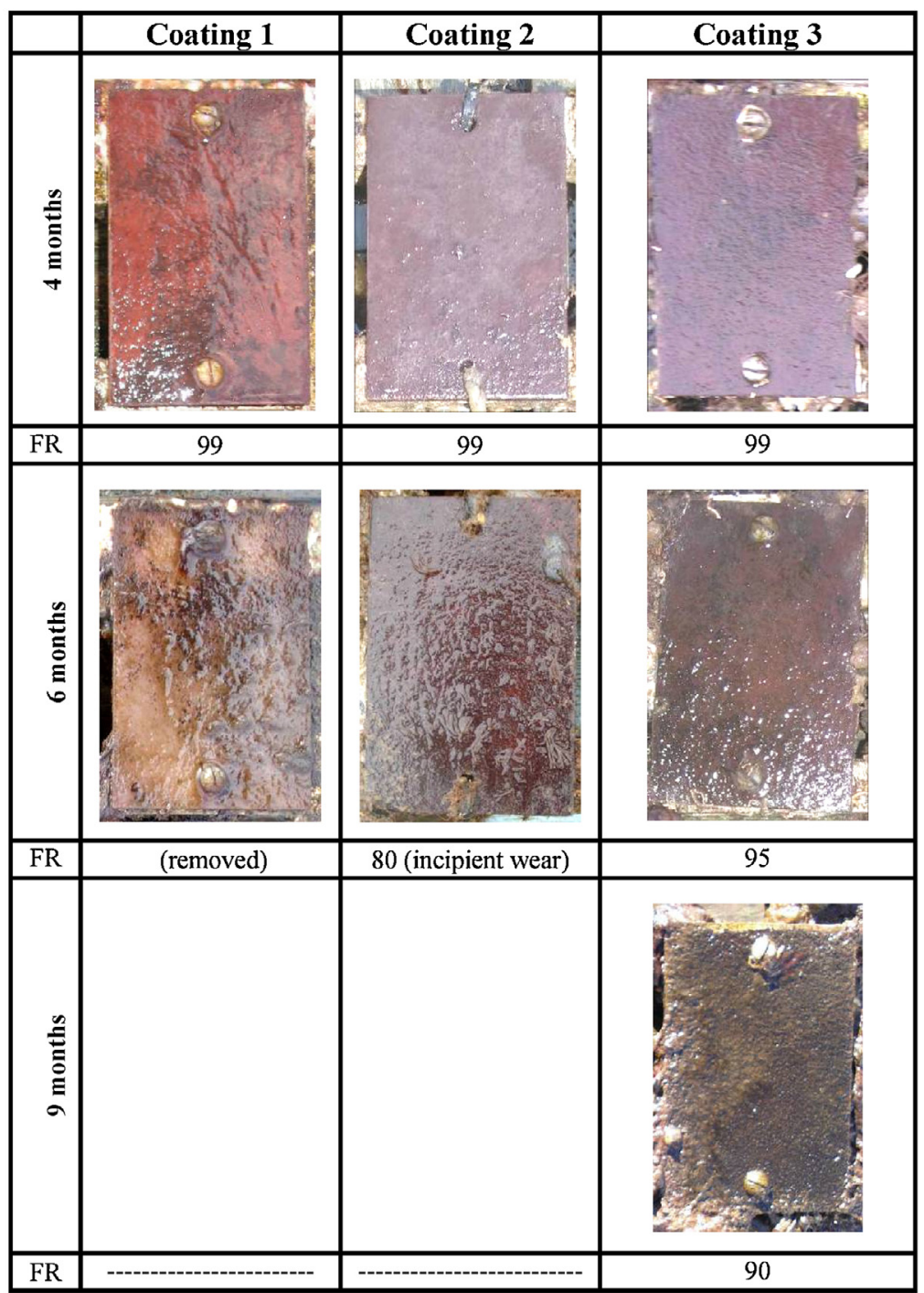

Fig. 8. (a) Photograph panels immersed in sea water environment: control panel and control coating. (b) Photograph panels immersed in sea water environment: coatings $1-3$.

\section{Conclusion}

The used of analytical techniques like SEM and ESEM along with others which can be performed in the laboratory, in a short period of time, proved to be extremely useful to assess coatings deterioration exposed to natural environments. An insight of film biodeterioration could be obtained by short term exposure test in NSW and subsequent evaluation of bacteria attachment. Coating 1 had the shortest service life and failed in laboratory immersion test and developed a bacterial film after $48 \mathrm{~h}$ in NSW. At the same time, the controls (without biocide) presented a more important biofilm which showed a greater diversity with the appearance of diatoms. Coatings 2 and 3 showed a more homogeneous and compact film without pores after immersion in ASW in SEM micrograph. Therefore, the absence of biofilm in NSW after $48 \mathrm{~h}$ and an extended life in NSW showed a correlation between results obtained with short time tests and long exposure test in natural environment.

The best results obtained with the coating that contained the tannin derivative obtained with the synthesis temperature up to $60^{\circ} \mathrm{C}$. This procedure allowed the increasing the zinc content, a solubility decrease and a higher bioactivity as compared with the "tannate" obtained at $20^{\circ} \mathrm{C}$.

\section{Acknowledgments}

The authors wish to thank the Consejo Nacional de Investigaciones Científicas y Técnicas (CONICET), Comisión de Investigaciones Científicas de la provincia de Buenos Aires (CIC), Agencia Nacional de Promoción Científica y Tecnológica (ANPCyT) and the Universidad Nacional de La Plata (UNLP) for the support to do this research work. They also thank to the Facultad de Ingeniería and the Centro de Investigación y Desarrollo en Ciencias Aplicadas (CINDECA) for facilitate the use of the ESEM and the SEM, respectively.

\section{References}

[1] M. Thouvenin, J.J. Peron, P. Guerin, V. Langlois, J.Y. Langlois, K. Vallee-Rehel, Prog. Org. Coat. 44 (2002) 85-92.

[2] F. Fäy, I. Linossier, J.J. Peron, V. Langlois, K. Vallée-Rehel, Prog. Org. Coat. 60 (2007) 194-206

[3] D.M. Yebra, S. Kiil, K. Dam-Johansen, Prog. Org. Coat. 50 (2004) 75-104. 
[4] W.A. Corpe, in: G. Bitton, K.C. Marshall (Eds.), Adsorption of Microorganisms to Surfaces, Wiley-Interscience Publication, USA, 1980, pp. 106-139.

[5] M. Wahl, Mar. Ecol. Prog. Ser. 58 (1989) 175-189.

[6] A. Garg, A. Jain, N.B. Bhosle, Int. Biodet. Biodeg. 63 (2009) 7-11.

[7] H.C. Flemming, T.R. Neu, D.J. Wozniak, J. Bacteriol. 189 (2007) 7945-7947.

[8] C.E. Zobell, E.C. Allen, J. Bacteriol. 29 (1935) 230-251.

[9] T. Kawamura, Y. Nimura, R. Hirano, J. Oceanogr. Soc. Jpn. 44 (1988) 1-5.

[10] M.E. Callow, J.A. Callow, Biologist 49 (2002) 10-14

[11] P.Y. Qian, S.C.K. Lau, H.U. Dahms, S. Dobretsov, T. Harder, Mar. Biotechnol. 9 (2007) 399-410

[12] I. Joint, K. Tait, M.E. Callow, J.A. Callow, D. Milton, P. Williams, M. Cámara, Science 298 (2002) 1207.

[13] D.M. Yebra, S. Kiil, C.E. Weinell, K. Dam-Johansen, Prog. Org. Coat. 57 (2006) 56-66.

[14] D. Howell, in: C. Hellio, D. Yebra (Eds.), Advances in Marine Antifouling Coatings and Technologies, Woodhead Publishing Limited, CRC, UK, 2009, pp. 422-442.

[15] M.J. Dampsey, Mar. Biol. 61 (1981) 305-315.

[16] H.M. Dalton, L.K. Poulsen, P. Halasz, M.L. Angles, A.E. Goodman, K.C. Marshall, J. Bacteriol. 176 (1994) 6900-6906.

[17] F. Fäy, I. Linossier, V. Langlois, D. Haras, V. Vallée-Rehel, Prog. Org. Coat. 54 (2005) 216-223.

[18] J.P. Maréchal, C. Hellio, Int. J. Mol. Sci. 10 (2009) 4623-4637.

[19] N. Bellotti, C. Deyá, B. del Amo, R. Romagnoli, Ind. Eng. Chem. Res. 49 (2010) 3386-3390.

[20] L.D. Chambers, K.R. Stokes, F.C. Walsh, R.J.K. Wood, Surf. Coat. Technol. 201 (2006) 3642-3652.

[21] ASTM D153-84, Standard Test Methods for Specific Gravity Pigments, ASTM International, USA, 2003.

[22] N. Bellotti, B. del Amo, R. Romagnoli, Prog. Org. Coat. 74 (2012) 411-417.

[23] ASTM D1141-98, Standard Practice for the Preparation of Substitute Ocean Water, ASTM International, USA, 2008.

[24] E. Ferreira, A. Nogueira, G. Souza, L. Batista, Food Chem. 86 (2004) 17-23.

[25] N. Dominy, E. Davoust, M. Minekus, J. Exp. Biol. 207 (2004) 319-324.
[26] S.B. Erdemoğlu, Ş. Gücer, Anal. Sci. 21 (2005) 1005-1008.

[27] G. Persoone, E. Jaspers, C. Clasus, Proceedings of the International Symposium on Ecotoxicological Testing for the Marine Environment, Ghent, Belgium, 1983, pp. $141-157$.

[28] V. Vetere, M. Pérez, M. García, M. Deyá, M. Stupak, B. del Amo, Surf. Coat. Int. 12 (1999) 386-389.

[29] G. Persoone, P.G. Wells, in: P. Sorgeloos, D.A. Bengtoson, W. Decleir, F. Jaspers (Eds.), Artemia Research and its Applications. Morphology, Genetics, Strain characterization, Toxicology, vol. 1, University Press, Belgium, 1987, pp. 259-275.

[30] M.C. Díaz Baez, G.D. Bulus Rossini, Y. Pica Granados, in: G. Castillo (Ed.), Métodos estadísticos para el análisis de resultados de toxicidad, Ensayos toxicológicos y métodos de evaluación de calidad de aguas, IDRC Books, 2004 (Chapter 5).

[31] R.E. Baier, in: G. Bitton, K.C. Marshall (Eds.), Adsorption of Microorganisms to Surfaces, Wiley-Interscience Publication, USA, 1980, pp. 60-87.

[32] J.A. Callow, M.P. Osborne, M.E. Callow, F. Baker, A.M. Donald, Colloid Surf. B: Biointerface 27 (2003) 315-321.

[33] R. Bastida, M. Trivi de Mandri, V. Lichtschein de Bastida, M. Stupak, Secc. Biol. Mar. (1980) 299-320.

[34] ASTM D3623-78a, Standard Test Method for Testing Antifouling Panels in Shallow Submergence, ASTM International, USA, 2004.

[35] ASTM D6990-05, Standard Practice for Evaluating Biofouling Resistance and Physical Performance of Marine Coating Systems, ASTM International, USA, 2005.

[36] R. Bastida, J.P. Martin, in: E.E. Boschi, M.B. Cousseau (Eds.), La vida entre mareas: vegetales y animales de las costas de Mar del Plata, INIDEP, Mar del Plata, 2004, pp. 49-58.

[37] B. Smith, Infrared Spectral Interpretation, CRC Press, USA, 1999, pp. 99-109.

[38] J.W. Cooper, Spectropic Techniques for Organic Chemists, Wiley-Interscience Publication, USA, 1980, pp. 22-52.

[39] R.T. Morrison, R.N. Boyd, Química Orgánica, Addison-Wesley Iberoamericana, Delaware, EUA, 1990, pp. 874-999. 